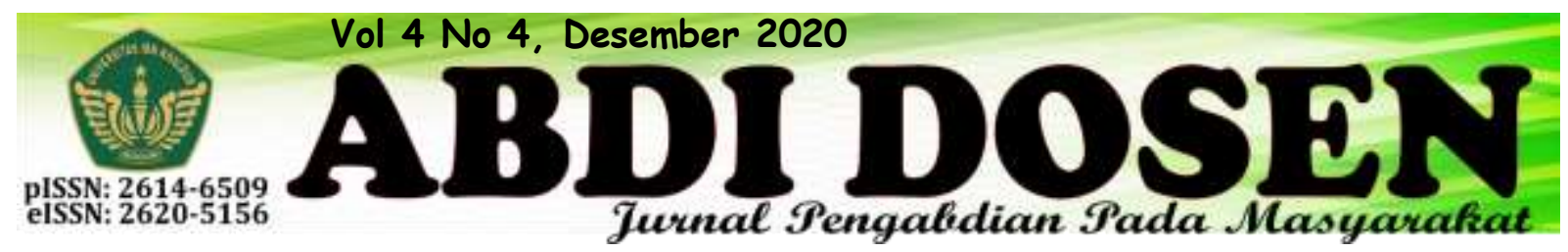

\title{
GOOGLE CLASSROOM SEBAGAI SARANA PEMBELAJARAN
}

\author{
Anita Dewi Ekawati ${ }^{1}$ dan Sri Kusuma Ningsih ${ }^{2}$ \\ anita.dewieka@uhamka.ac.id ${ }^{1}$ \\ Fakultas Keguruan dan Ilmu Pendidikan, Universitas Muhammadiyah Prof. DR. HAMKA ${ }^{1,2}$
}

\begin{abstract}
ABSTRAK
Kebijakan Belajar Dari Rumah (BDR) yang dikeluarkan Kemendikbud menuntut guru dan siswa untuk tetap melakukan kegiatan belajar dan mengajar meskipun tidak tatap muka. Guru dituntut untuk lebih kreatif, inovatif, dan menjalin komunikasi yang baik dengan siswa dan orang tua siswa. Google Classroom adalah salah satu aplikasi yang mudah diakses bagi guru, siswa dan orang tua. Kegiatan Pengabdian Kepada Masyarakat (PKM) berjudul "Google Classroom Sebagai Sarana Pendukung Pembelajaran" yang dilaksanakan di TK 'Aisyiyah 86 pada 4 Agustus 2020 diharapkan dapat membantu guru dalam memberikan pelajaran, mengorganisir tugas dan mengakumulasi nilai. Selain itu diharapkan orang tua membantu siswa untuk dapat disiplin dalam mengumpulkan tugas.
\end{abstract}

\section{Kata Kunci : BDR, Google Classroom, Guru, Siswa}

\section{PENDAHULUAN}

Pandemi Covid-19 di dunia termasuk Indonesia membuat adanya kebijakan baru dari pemerintah untuk melakukan social distancing sesuai anjuran WHO. Dengan diberlakukannya kebijakan tersebut Kementerian Pendidikan dan Kebudayaan (Kemendikbud) menerbitkan Surat Edaran Mendikbud Nomor 4 Tahun 2020 tentang proses belajar mengajar yang tetap berjalan dengan cara daring atau online atau disebut juga sebagai Belajar Dari Rumah (BDR). Pembelajaran secara daring atau online dapat memanfaatkan aplikasi yang dapat dipasang di laptop dan telepon genggam seperti Schoology, Google Classroom, Edmodo, dan aplikasi lainnya (Pratiwi, 2020). Melalui media tersebut diharapkan proses belajar mengajar dapat berjalan maksimal.

Salah satu aplikasi yang banyak digunakan saat ini adalah Google Classroom. Google Classroom adalah salah satu layanan dari Google Apps for Education (GAFE) yang dapat membagikan dan menggolongkan setiap penugasan tanpa kertas (Ulum, Fantiro, \& Rifa'i, 2019). Aplikasi ini dapat dipasang secara gratis dan mudah digunakan oleh semua kalangan. Pada aplikasi tersebut terdapat tiga menu utama untuk guru ('stream', 'students', dan 'about') dan dua menu utama untuk murid ('stream' dan 'students') (Solihati \& Mulyono, 2017). Google Classroom juga dapat digunakan untuk memperbarui materi yang sesuai dengan silabus dan buku teks.

Dengan memanfaatkan aplikasi Google Classroom diharapkan data belajar dan mengajar dapat terorganisir. Guru juga dapat memberikan data nilai atau pun akumulasi nilai dengan mudah. Dengan demikian guru dapat lebih menghemat waktu. Selain itu, melalui aplikasi ini siswa dilatih untuk disiplin dalam mengumpulkan 
tugas sesuai dengan tenggat waktu yang diberikan oleh guru. Orang tua siswa juga dapat terlibat untuk membantu siswa dalam penggunaan gadget. Komunikasi pun dapat mudah terjalin antara guru, siswa, dan orang tua siswa.

Guru harus mencari cara untuk mentransfer ilmunya tanpa tatap muka. Tuntutan untuk selalu kreatif dan inovatif dalam mengajar terkendala dengan kurangnya pelatihan penggunaan tehnologi. Pelatihan menggunakan Google Classroom diharapkan menjadi solusi bagi permasalahan guru dalam mengajar secara daring atau online pada kepala sekolah dan guru-guru TK 'Aisyiyah 86 Cipayung, TK 'Aisyiyah 101 Cipayung, dan TK 'Aisyiyah Bustanul Athfal Ciracas.

\section{Keadaan Geografis}

Secara geografis TK 'Aisyiyah 86 Cipayung berada di kota Jakarta Timur. Alamat TK Jl. Flamboyan Blok F 16-20-22, RT. 5 RW. 1, Cipayung, Cipayung Jakarta Timur. Jarak dari FKIP UHAMKA ke lokasi mitra kurang lebuh $8 \mathrm{~km}$

\section{METODE PEGABDIAN}

Tahap 1: Persiapan (Survei dan Wawancara dengan Mitra)

Tim PKM mengadakan survei dan wawancara langsung dengan kepala sekolah dan guru TK 'Aisyiyah 86 Cipayung, TK 'Aisyiyah 101 Cipayung, dan TK 'Aisyiyah Bustanul Athfal Ciracas.

Tahap 2: Rapat Koordinasi dengan Tim PKM

Tim PKM melaksanakan rapat koordinasi dalam hal pemantapan kegiatan pengabdian. Beberapa hal yang akan dibahas pada rapat ini di antaranya adalah materi pelatihan dan pengaturan agenda kegiatan selama pelatihan berlangsung.

Tahap 3: Pengolahan Informasi

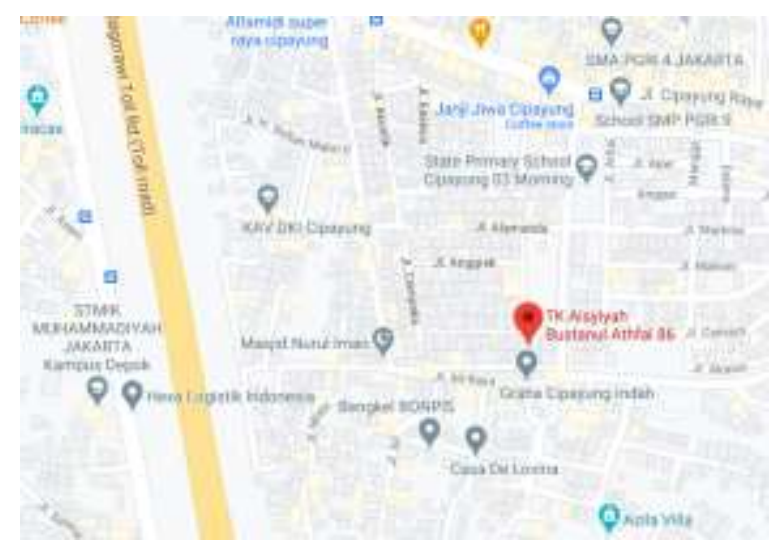

\section{Kondisi Pendidik}

Berdasarkan analisis situasi dan permasalahan mitra, maka perlu diadakan pelatihan bagi kepala sekolah dan guru untuk meningkatkan kemampuan pendidik dalam tehnologi dan mempermudah pembelajaran secara daring. Dengan pelatihan ini maka solusi yang ditawarkan sebagai berikut:

1.Memberikan peningkatan wawasan dan pemahaman kepada para guru tentang cara penggunaan Google Classroom.

$\begin{array}{ccr}\text { 2. Membantu } & \text { pendidik dalam } \\ \text { mempraktekan } & \text { metode mengajar } \\ \text { daring dengan } & \text { Google Classroom. }\end{array}$

Mengumpulkan data dan referensi yang dibutuhkan untuk pembuatan materi pelatihan.

Tahap 4: Penyusunan Materi Pelatihan Membuat power point.

Tahap 5: Pelaksanaan Program

a) Waktu dan Tempat Kegiatan

Kegiatan pelatihan dilaksanakan pada 4 Agustus 2020 di TK 'Aisyiyah 86 Cipayung.

b) Peserta Kegiatan

Pelatihan ini akan dihadiri kepala sekolah dan semua guru dari masingmasing TK.

\section{c) Kegiatan Pelatihan}

Acara yang akan dilaksanakan terbagi menjadi dua sesi. Sesi pertama adalah 
kegiatan seminar dan sesi kedua adalah kegiatan workshop. Kegiatan seminar dilakukan dengan tujuan memberikan gambaran, pandangan dan konsep tentang pembelajaran daring dengan menggunakan.

d) Kegiatan Workshop

Kegiatan Workshop akan dilaksanakan sebagai kegiatan lanjutan dari kegiatan seminar. Tujuan dari kegiatan workshop ini adalah memberikan kesempatan kepada kepala sekolah dan guru untuk dapat mempraktekkan langsung metode yang telah dipaparkan oleh pemateri seminar.

Pendidik membuka menginstall Google Classroom pada HP atau membuka pada laptop masing-masing. Pendidik dan pembicara bersama-sama mengaplikasikan secara runut Google Classroom. Pendidik saling bergantian mempraktekan menjadi guru dan siswa pada aplikasi tersebut dengan bimbingan pembicara.

Tahap 6: $\quad$ Pembuatan Laporan

\section{Jadwal Kegiatan}

\begin{tabular}{|c|c|c|c|c|c|c|c|c|c|c|c|c|c|}
\hline \multirow{3}{*}{ No } & \multirow{3}{*}{ Jenis Kegiatan } & \multicolumn{12}{|c|}{ Waktu Pelaksanaan } \\
\hline & & \multicolumn{4}{|c|}{ Juni 2020} & \multicolumn{4}{|c|}{ Juli 2020} & \multicolumn{4}{|c|}{ Agustus 2020} \\
\hline & & 1 & 2 & 3 & 4 & 5 & 6 & 7 & 8 & 9 & $\begin{array}{l}1 \\
0\end{array}$ & $\begin{array}{l}1 \\
1\end{array}$ & 12 \\
\hline 1 & $\begin{array}{l}\text { Persiapan (Survei dan Wawancara } \\
\text { dengan Mitra) }\end{array}$ & & & & & & & & & & & & \\
\hline 2 & $\begin{array}{l}\text { Koordinasi dengan Tim PKM } \\
\text { (Pembagian Tugas) }\end{array}$ & & & & & & & & & & & & \\
\hline 3 & Pengolahan Informasi & & & & & & & & & & & & \\
\hline 4 & Penyusunan Materi Pelatihan & & & & & & & & & & & & \\
\hline 5 & Sosialisasi Program Pelatihan & & & & & & & & & & & & \\
\hline 6 & Pembuatan Laporan & & & & & & & & & & & & \\
\hline
\end{tabular}

\section{REALISASI PROGRAM}

Pelaksanaan pengabdian kepada masyarakat dilaksanakan secara tatap muka dengan tetap menerapkan social distancing dan memakai masker adan face shield pada hari selasa tanggal 4 Agustus 2020. Kegiatan bertempat di TK 'Aisyiyah 86 Jl. Flamboyan Blok F 16-20-22, RT. 5 RW. 1, Cipayung, Cipayung, Jakarta Timur.

Kegiatan pengabdian kepada masyarakat dimulai dengan registrasi peserta pada pukul 13.00 melalui google form. Peserta yang hadir sebanyak 14 orang. Pelaksanaan pengabdian dimulai dengan sambutan oleh Kepala Sekolah TK 'Aisyiyah 86, ibu Winarsih, M.Pd. Dalam sambutannya, Ibu Winarsih, M.Pd. menyampaikan apresiasi kepada UHAMKA karena melaksanakan kegiatan yang sangat sesuai dengan kebutuhan guru. Beliau berharap UHAMKA semakin sering menyelenggarakan kegiatan pengabdian kepada masyarakat di TK' Aisyiyah sebagai bentuk dukungan untuk memajukan pendidikan di 'Aisyiyah. Setelah pemberian 
kata-kata sambutan oleh Ibu Winarsih, M.Pd., acara selanjutnya adalah sambutan ketua PKM kegiatan saat ini, Anita Dewi Ekawati, S.S., M.Pd.. Dalam sambutannya Anita menyampaikan rasa terima kasih karena telah diberikan kesempatan melaksanakan kegiatan PKM di TK 'Aisyiyah dengan peserta kepala sekolah dan guru-guru TK 'Aisyiyah 86 Cipayung, TK 'Aisyiyah 101 Cipayung, dan TK 'Aisyiyah Bustanul Athfal Ciracas. Semoga kerjasama ini dapat berlanjut pada kegiatan PKM yang lain. Acara dilanjutkan dengan penjelasan teknis kegiatan pengabdian yang disampaikan oleh Anita Dewi Ekawati, S.S., M.Pd.

Pada pukul 13.45, dimulailah pemaparan materi oleh Sri Kusuma Ningsih, M.Pd. menggunakan Zoom dengan materi tentang kegunaan dan cara menggunakan aplikasi Google Classroom. Selanjutnya, Anita Dewi Ekawati, S.S., M.Pd. secara tatap muka memperdalam penjelasan. Dalam materinya, Anita dan Sri menyampaikan tentang pengertian daring dan bagaimana cara menerapkan Google Classroom dalam pengajaran di PAUD/TK.
Peserta yang hadir diminta untuk membuka Google Classroom pada laptop masingmasing peserta dan mengunduh aplikasi tersebut di HP. Setelah itu peserta dijelaskan mengenai bagian dan fungsi pada aplikasi tersebut. Kemudian dilanjutkan dengan bersama-sama menggunakan aplikasi tersebut.

Pukul 15.00 peserta secara bergantian menjadi guru dan siswa pada aplikasi Google Classroom. Hal ini bertujuan untuk saling memberikan saran dan masukkan agar peserta tidak kesulitan dalam penerapan aplikasi Google Classroom dalam pembelajaran. Anggi, mahasiswa alumni membantu peserta secara daring dan Anita secara tatap muka. Pukul 14.30 acara PKM ditutup oleh Anita Dewi Ekawati, S.S., M.Pd. Pada PKM ini tim PKM menyerahkan bingkisan yang berisi disinfektan sebagai wujud dukungan kepada pemerintah untuk Perilaku Hidup Bersih dan Sehat (PHBS) melawan Covid 19. Video kegiatan sudah diunggah di YouTube https://youtu.be/5r9KwLAWL80.

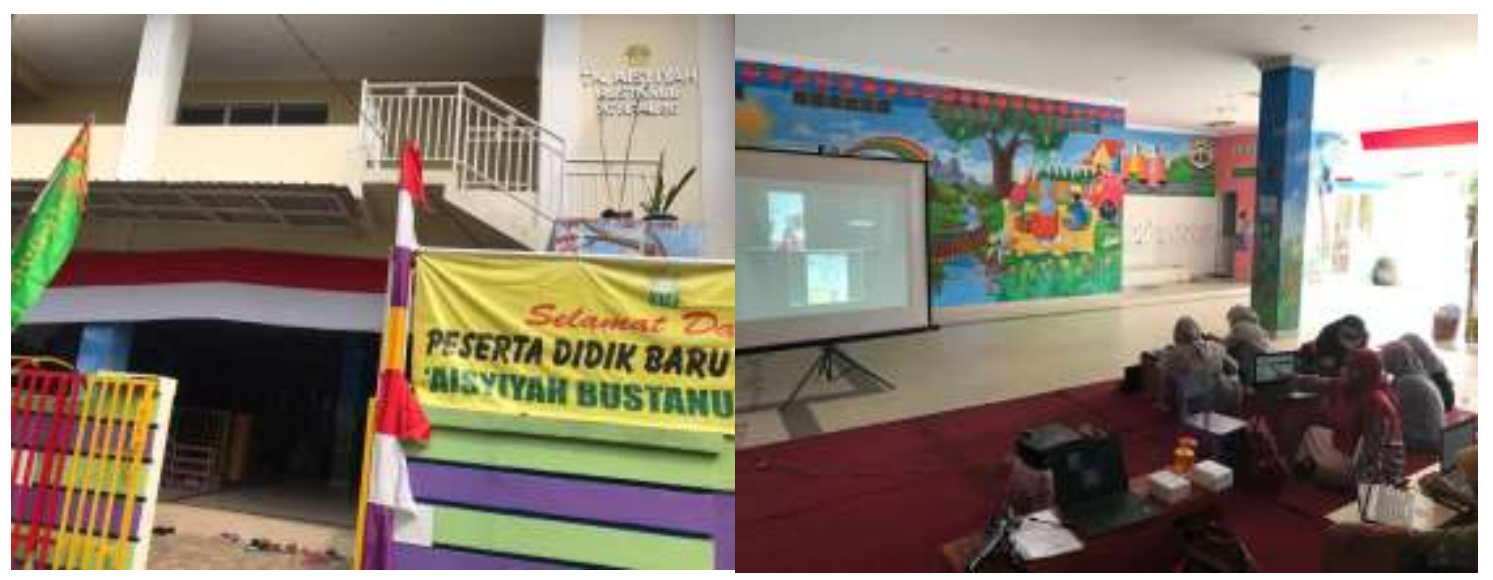




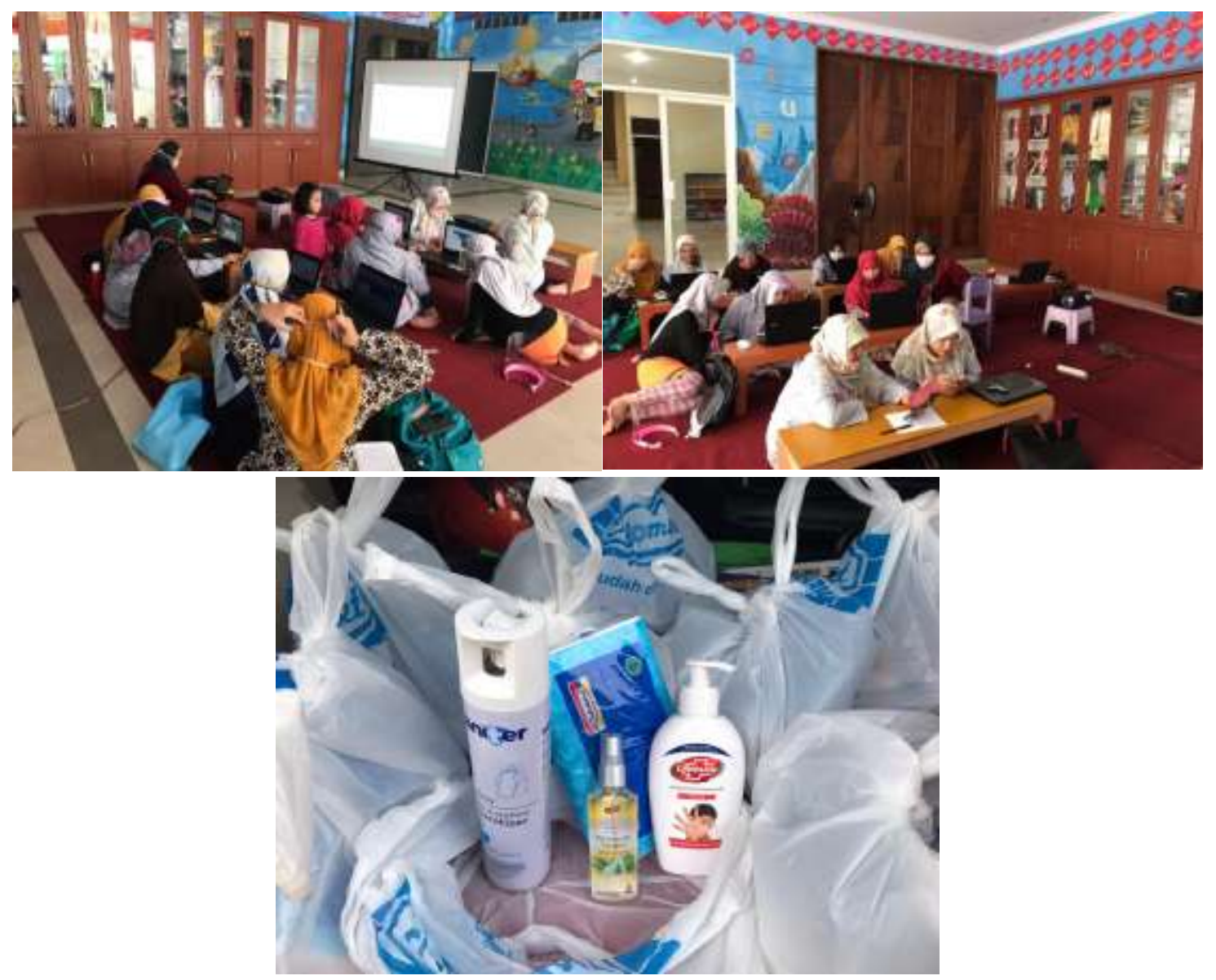

\section{KESIMPULAN}

Kemampuan dalam mengajar daring sebaiknya dikuasai oleh semua pendidik guna efektivitas dalam penggunaan waktu dan alat. Selain itu pengajaran daring juga dapat menarik perhatian siswa dan mengembangkan kreativitas dan inovasi pendidik.Banyak ide yang dapat tersampaikan dengan dibantu kemahirn penggunaan tehnologi.
Berdasarkan hasil evaluasi pelaksanaan kegiatan pengabdian kepada masyarakat, saran yang diberikan:

Perlu adanya peningkatan frekuensi pelaksanan kegiatan pengabdian kepada masyarakat di TK 'Aisyiyah sebagai bentuk dukungan dan pendampingan UHAMKA terhadap kemajuan pendidikan TK 'Aisyiyah terutama dibidang tehnologi pendidikan. 


\section{DAFTAR PUSTAKA}

Pratiwi, E. W. (2020). Dampak COVID-19

Terhadap Kegiatan Pembelajaran

Online di Sebuah Perguruan Tinggi Kristen di Indonesia. Perspektif Ilmu Pendidikan, 34(1), 1-8.

Solihati, N., \& Mulyono, H. (2017). A Hybrid Classroom Instruction in Second Language Teacher Education ( SLTE ): A Critical Reflection of Teacher Educators. IJET, 12(5), 169-
180.

Ulum, B., Fantiro, F. A., \& Rifa'i, M. N. (2019). Pemanfaatan Google Apps di Era Literasi Digital Pada Siswa Sekolah Dasar. Lentera: Jurnal Ilmiah Kependidikan, 14(2), 22-31. https://doi.org/10.33654/jpl.v14i2.84 3. 